\title{
Innovation Paths of Party Construction for the Cultural Construction of College Affiliated Hospitals
}

\section{Juan Wang*}

The Affiliated Hospital of Youjiang Medical University for Nationalities, Baise City 533000, Guangxi Province, China. E-mail: 3063339651@qq.com

\begin{abstract}
Building the characteristic brand of Party building in affiliated hospitals of colleges and universities is conducive to strengthening the combination of Party building and cultural construction. Also, it is beneficial to enhance the leading role of Party building. Based on the author's study and work experience, this work first analyzed the significance of creating characteristic brand of Party building in affiliated hospital of colleges, and then elucidated its deficiency. Finally, some possible ways to create party-building characteristic brands were proposed as the way forward. Keywords: Affiliated Hospital; Cultural Construction; Party Building Brand
\end{abstract}

\section{Introduction}

The report of The 19th National Congress of the Communist Party of China pointed out that culture can provide people with strong ideological guarantee, strong spiritual strength, and rich moral nourishment. Therefore, it is necessary to constantly strengthen cultural construction. The main work of affiliated hospitals of colleges and universities includes medical treatment, teaching and scientific research ${ }^{[1]}$. It is necessary to continuously strengthen the core competitiveness of management, technology and talents. At the same time, it is also necessary to establish a sense of service, cultivate a humanized people-oriented service concept, and let culture enhance its core competitiveness and escort all work. Accordingly, the construction of hospital culture is an indispensable important factor for the development of hospitals. The core of hospital culture is the collective values, which is a kind of universally recognized culture formed by all staff in the long-term medical practice process, and has a strong role of cohesion, guidance and motivation. Usually, the components of hospital culture include material culture, system culture and spiritual culture. Some other categories of hospital culture are the hospital's code of conduct, moral standards, history of development, values and beliefs, as well as the cultural atmosphere through the hospital's image characteristics, service quality and organizational structure ${ }^{[2]}$. Hospital culture pays attention to people's basic needs and emphasizes people-oriented concept.

\section{The significance of creating characteristic brand of Party building in affiliated hospitals of colleges and universities}

Brand originally appeared in the commercial field, which refers to people's trust in enterprises and their products, cultural value and after-sales service, and is a kind of universal recognition and evaluation. It is a kind of long-term intangible asset with economic value ${ }^{[3]}$. Its differences need to be expressed by unique, abstract and distinguishable psy-

This is an open-access article distributed under the terms of the Creative Commons Attribution Non-Commercial License (http://creativecommons.org/licenses/by-nc/4.0/), which permits unrestricted non-commercial use, distribution, and reproduction in any medium, provided the original work is properly cited. 
chological concepts, and constantly form a comprehensive reflection in people's consciousness. There are similarities and differences between the characteristic brand built by the Party and that in the commercial field, which is special, long-term, valuable and intangible. However, there are also different points since the Party building characteristic brand requires the brand to be more rigorous and normative, requires the o form based on certain principles and system requirements, and pays attention to innovation. The affiliated hospitals of colleges should attach importance to the establishment of distinctive brand of Party building corresponding to the central planning of colleges and universities, establish the concept of work, and do a good job in the innovation of working methods. In addition, the Party building characteristic brand in the affiliated hospitals of colleges and universities should establish their own position. They should serve the vast numbers of teachers and students, patients, perform the coordination of medical education, keep the advanced nature of the original intention of Party members, and innovate the management concept of grassroots Party organizations. The establishment of distinctive brands requires carriers, such as certain facilities, venues, logos, party emblems, party flags and media. In addition, it is important to perform a certain collective effect and do a good job in promotion.

Party building and hospital culture construction in the affiliated hospitals of colleges and universities complement each other. By creating characteristic brand of Party building, hospital culture construction can be guided and hospital soft power can be enhanced ${ }^{[4]}$. First, it is conducive to improving the cohesion of employees. Through the establishment of characteristic brand of Party building in affiliated hospitals, all the staff led by the Party can form a certain collective consciousness, and be united to carry out all the work. Second, it is conducive to strengthening the external influence of affiliated hospitals. Through a series of brand building activities, affiliated hospitals cooperate with various units to publicize and disseminate the hospital's ideas, products and services, invisibly making other units and all sectors of society form a certain recognition and identity, so that the image of the hospital can be improved. Third, it is conducive to building up the service consciousness of Party members. In the process of building the Party's brand, Party members should carry out the Party's principles and policies, adhere to the mass line, uphold the consciousness of serving the people wholeheartedly, and play a vanguard and exemplary role in the unit. Additionally, they also should serve the patients wholeheartedly with noble medical ethics and medical style, invisibly improve the service quality of affiliated hospitals, promote the good development of doctor-patient relationship ${ }^{[5]}$, and create a good hospital, thus providing positive energy for cultural construction.

\section{Deficiency of characteristic brand of Party building in affiliated hospitals of colleges and universities}

At present, the innovation of characteristic brand of Party building in affiliated hospitals of colleges and universities has made initial progress, but there are still many problems.

First, the lack of brand awareness. At present, the work of Party building in affiliated hospitals of colleges and universities still stays in the institutionalization and standardization of the Party branches without a good sense of innovation, which leads to outdated working methods and working systems ${ }^{[6]}$. Branding is an important way to innovate the work of Party branches. Second, brand positioning has not been established well. The brand building of affiliated hospitals of colleges and universities has not been combined with the characteristics of their own units, and the construction of branches has not been combined with the characteristics of staff and resource conditions of branches. Third, the lack of institutional constraints. Some affiliated hospitals of colleges and universities have established distinctive brand of Party building, but only scratching the surface. Since there is no certain system to regulate, the development of this work does not have overall planning and arrangement, but just stays in the basic stage of exploration. Although the hardware facilities and personnel are ready, they have not played their role for a long time and regularly. Fourth, the lack of publicity and promotion. In the process of brand building, some affiliated hospitals of colleges and universities do not carry out publicity reports. Brand creation does not have a fixed platform for display, or the display way is single and aging. Fifth, it is separate from the business effort. The establishment of 
characteristic brand of Party building should combine Party members and the masses, the Party building and daily business of hospital, and the Party building and main work of hospital ${ }^{[7]}$. However, in the current process of building characteristic brand of Party building, there is no awareness of "Party building + business" and no consideration of the integration of brand design and hospital culture, positioning, development planning and other factors.

\section{Ways to create Party building characteristic brands in affiliated hospitals of colleges and universities}

The establishment of Party building brand is an indispensable important factor in the cultural construction of affiliated hospitals in colleges and universities. If the work of building characteristic brand by the Party can be done perfectly, the work of Party building is bound to be vigorous, as well as the development of the hospital culture.

\subsection{Establishing the consciousness of Party building characteristic brand}

The affiliated hospitals of colleges and universities should encourage all staff to establish the awareness of the Party building brand, which is the foundation of the Party building work and the key factor of the brand building work. First, the hospital should take the Party brand building as an important goal, and take it as an important standard to judge the work of the Party branch. Second, in the process of brand building, the hospital should have innovative work philosophy, which should be reflected in the aspects of system, organizational framework, service attitude and activity content. Third, the hospital should standardize the process of brand building and various work, and regard brand building as the spiritual pursuit of all branches and Party members.

\subsection{Learning from the means of building commercial brands}

In the business field, brand is usually used for marketing. In the work of Party building in affiliated hospitals of colleges and universities, commercial brand marketing can also be used to carry out extensive propaganda, making the image of Party organizations more and more three-dimensional and lively. In order to develop the brand building better, the hospital should learn from the experience of enterprises, use all means and resources to show the meaning and connotation of the Party building brand. Based on this, doing a good job in all activities planning and specific programs and serving the masses can improve the Party building brand image. Party building brand has a good influence, which can make resources further integration and achieve the scale effect ${ }^{[8]}$. In order to avoid the monopoly of resources in the process of Party building, the hospital should actively coordinate and communicate according to the needs of brand building and development, and integrate various resources into that of Party building, so as to achieve the smooth implementation of Party building and effective integration of resources.

\subsection{Formulating the Party building brand system}

The establishment of the system can effectively regulate the activities. The reason why the hospital Party building brand can be created is to ensure the orderly and continuous development of activities under the system constraints. Based on the specific requirements of time, space, organizers and participants in all activities, the normalization of Party building activities can be guaranteed. At the same time, the hospital should also strengthen the shaping of the party organization image, ensure the establishment of the brand through the consistency of the external image, such as requiring the party organization to have consistent badges, clothing and slogans, and promote the brand image with the help of Internet technology or new media, so as to receive support from people.

\subsection{Contacting with business work closely}

Hospital culture has brought a good atmosphere to the Party building work, which should also be built around the hospital culture and history. When the affiliated hospitals of colleges and universities establish the characteristic brand of Party building, it is necessary to determine whether it is consistent with the specialty and characteristics of the 
hospital, and whether it is consistent with the central goal of the hospital. At the same time, the hospital should combine the natural environment, geographical environment, human environment, specific problems and specific analysis to make full use of the macro strategy to develop the brand of Party building. In the meantime, the construction of the Party branch of the hospital should be combined with the business work of the branch and the cultural characteristics of the branch. Through the activities of each branch, the various businesses of affiliated hospitals in colleges and universities are improved and optimized, thus improving the quality of medical treatment and service. Departments and Party branches jointly carry out activities, making the activities more targeted and feasible.

\section{Conclusion}

The innovations of the Party building work can not only enhance the centripetal force of the staff and workers in the hospital, but also improve the existing development of the hospital, so that the level of comprehensive development of the hospital can be further improved. In order to show the innovation level of the hospital Party building work, it is necessary to strengthen the hospital culture construction level, and carry out the optimization and renewal of the existing hospital Party building work mode under the condition of the hospital culture construction. To this end, this paper sequentially analyzed the significance and deficiency in creating characteristic brand of Party building for affiliated hospitals of colleges and universities, and some possible ways were proposed to create party-building characteristic brands.

\section{Acknowledgement}

The paper is periodic result of the self-financing project of Guangxi Medicine and Health in 2017, Research on the Applications of Clinical Micro-Class Teaching Methods - From the Angle of Theory about Social Cognition (No.: Z20170233).

\section{References}

1. Qi X. Research on the current situation and improvement measures of the party construction at the grassroots level in the new era (in Chinese). Economic Management (Abstract Edition) 2016; (1): 293.

2. Wang Y. Fostering the characteristic brand of grass-roots Party building and promoting the cultural construction of public hospitals (in Chinese). Modern Hospital 2018; 18(10): 33-35+39. doi: CNKI:SUN:XDYU.0.2018-10-011.

3. Chen X. On the current situation and Countermeasures of improving the guarantee mechanism of grass-roots party construction (in Chinese). Charming China 2014; (6): 364.

4. Zhao L, Sun Q. Current situation and cause analysis of grass-roots Party building in Colleges and universities (in Chinese). Science and Technology Outlook 2016; 26(10): 335. doi: 10.3969/j.issn.1672-8289.2016.10.294.

5. Li J, Zhang P, Xu B. Creating party-building brand, innovating party-building value (in Chinese). China Electric Power Enterprise Management 2018; 515(2). doi: CNKI:SUN:ZGDQ.0.2018-02-041.

6. Shang L, Liu P. Promoting Party building and innovation at grass-roots level through brand creation (in Chinese). Journal of South China University of Technology (Social Science Edition) 2014; (16): 50-54.

7. $\mathrm{Ni} \mathrm{C}, \mathrm{Xu} \mathrm{W}$. Innovation and exploration practice of grassroots party construction carrier integrated into the core work of education from the perspective of (in Chinese). Education and Teaching Forum 2018; 370(28): 179-181. doi: CNKI:SUN:JYJU.0.2018-28-081.

8. Sun L, Xu J. On Xi Jinping's new requirements for the ideological and political work in colleges and universities in the new era of socialism with Chinese characteristics (in Chinese). Study of Socialist Core Values 2018; (6) $67-74$. 